\title{
ASSESSMENT OF FRUIT DEFECTS AND ECONOMIC LOSS OF SOME SOFT DATE PALM CULTIVARS (PHOENIX DACTYLIFERA L.) IN NORTH DELTA, EGYPT
}

\author{
El-ANSARY, M. A. - OMAR, A. K. - SAlAMA, A. ${ }^{*}$ - Helal, S. M. \\ Horticulture Department, Faculty of Agriculture, Kafrelsheikh University \\ Kafr Elsheikh 33516, Egypt \\ (e-mail/phone: mohamed.elansary@agr.kfs.edu.eg,+20-100-659-1818; \\ alaa.omr@agr.kfs.edu.eg, +20-109-740-8240 \\ *Corresponding author \\ e-mail: abdelmoety.salama@gmail.com; phone: +20-109-513-1735
}

(Received $2^{\text {nd }}$ Feb 2019; accepted $21^{\text {st }}$ Mar 2019)

\begin{abstract}
This research was carried out to quantify the amount of defected fruits, outlining the causes of defect, and their negative economic impact, in terms of total fruit loss (US\$), production cost (US\$), total area of cropping land (hectare), and irrigation water $\left(\mathrm{m}^{3}\right)$ of 'Samani', 'Hayani', 'Bent Aisha', 'Oreebi', and 'Zaghloul' soft date palm (Phoenix dactylifera L.) cultivars grown in North Delta, Egypt. Random fruit samples were taken at harvest date of each cultivar from Rasheed and Baltim districts and divided into two sets; sound fruit (free of visible defects) and defected/discarded fruit. The defected fruits set was classified based on the type of defect into; misshape, unpollinated fruit (shees), decay and mold, dirt, discolored, dry fruit, insect damage, over-ripped fruit, shrivelling, under size, unripe fruit, no calyx, and mechanical injuries. Each type of defect was calculated as a percentage of the total weight of the defected fruit. Fruit loss was determined as follow; 'Hayani' (19.66-26.77\%), 'Samani' (23.03-25.33\%), 'Oreebi' (16.79-25.00\%), 'Bent Aisha' (9.66-15.68\%) for 2015/2016-2016/2017 seasons respectively, 'Zaghloul' (5.55\%) for 2016-2017. Total monetary loss based on the farm price was about 8,641,908-9,232,793 for the studied cultivars. Total loss in terms of cropping land was about 1,771-1,939 ha with a total loss of $1,511,616-1,654,890$ in production cost and 11,2-12,3 million $\left(\mathrm{m}^{3}\right)$ of the irrigation water. Fruit without calyx was the main defect of all the studied cultivars, except 'Oreebi' during both seasons.

Keywords: postharvest loss, date defects, losses cost evaluation, irrigation water loss, fruit loss
\end{abstract}

Abbreviations: EGP: Egyptian pounds, MALR: Ministry of Agriculture and Land Reclamation

\section{Introduction}

Date palm (Phoenix dactylifera $\mathrm{L}$.) is one of the key fruits in dry and semidry regions (Chao and Krueger, 2007). Egypt considers the highest country for date production over the world with 1590414 ton (FAO, 2019), around $18 \%$ of the global date production. There are three types of date fruits, soft, semi-dry and dry, about $45 \%$ of date fruits in Egypt are soft (MALR, 2018). The most common soft types in Egypt are 'Hayani', 'Zaghloul', 'Samani', 'Bent Aisha', and 'Oreebi', (they present around 43\% of the soft types in Egypt) (MALR, 2018). In cooperation with FAO and other international agencies, Egypt has developed, in September 2016, strategy for the development of date palm and dates sector. One of its main pillars is to enhance dates export through high quality fruits (FAO, 2016). An important step to produce and maintain high quality date fruits and reduce loss and waste is to know the volume and types of defects (El-Habbab et al., 2017). Yahia et al. (2014) concluded that some of the vital means to produce good quality dates and to maintain its postharvest quality include: selecting the right type of male clones for pollination, developing appropriate date palm mechanization, especially for pollination and harvesting, adequate use of the cold chain, packaging and packages, 
food safety measures, insect control and prevention of re-infestation during postharvest processes. The results of FAO (2011) study pointed out that roughly one-third of food produced for human consumption is lost or wasted globally. The types of food loss and waste in low-income countries are primarily linked to the limited financial resources, low managerial and technical capacities in harvesting performances, storage and cooling facilities in hard climatic conditions, inferior infrastructure, packaging and marketing systems. Yahia et al. (2014) reported that only about $10 \%$ of the world production of dates is handled in global trade due to various factors including inadequate handling practices and insufficient information for small farmers, who are the main producers. They also pointed out to the need to investigate and refine several subjects such as: improvements of harvesting systems; safe means for insect and pathogen control; adequate packaging and storage conditions; and more biochemical studies on sugar interactions, tissue softening, and browning. In Arabian Peninsula countries, fermentation, insect infection, birds and mechanical damage are the common types of postharvest loss of dates; the produced dates do not fulfil International Regulations and Standards required for export. Elsayed and Abdel Gleel (2013), in Egypt, had reported that, the average dates loss of ten-year (2000-2010) at harvesting were 10-15\% and $8.1 \%$ during postharvest processes, this is due to mechanical (harvesting, sorting, grading, and transportation) or biological (pests and insects) reasons. El-Habbab et al. (2017) investigated dates loss at harvest time of three cultivars in four locations in Saudi Arabia, that include shees \& besr, bird's damage, falling, insects and dust mite. They found that the loss varied from location to location as well as within cultivars in the same location. The average level of loss during the marketing stage was about 5-10\% in most varieties and locations except Ajweh in Riadh (2.7\% only). Lemlem et al. (2018) found that conventional procedures of date palm production were applied in Afar Regional State, Ethiopia and constrained with high incidence of insect pests. They recommended training sessions on good agricultural practices and to improve management, and postharvest handling practices. As a result of thirty years working on postharvest loss prevention, Boye and Muck (2015) concluded that a series of prerequisites including reliable funding over extended period, continuity in sciencebased programs and project approaches, considerations of technical and socio-economic factors are needed for implementing sustainable postharvest loss prevention. Identification of main causes of date defects and determination its percentage might contribute in filling the information gap of support to overcoming the weaknesses of date palm sector identified in Egypt date palm strategy (FAO, 2016), specifically weak tendency towards good agricultural practices to produce high quality dates.

The objectives of this work were to evaluate the cost, magnitude and type of main defects for some soft date palm cultivars at harvesting date, in North Delta, Egypt.

\section{Materials and methods}

The work was carried out in two main areas for soft date production in Egypt, Rasheed and Baltim districts which are located in North of Behira and Kafr El-Sheikh governorate respectively, at the North of Nile Delta, Egypt, on date palm fruits (Pheonix dactylifera, L.) of 'Samani', 'Hayani', 'Bent Aisha', and 'Oreebi', soft cultivars during 2015/16 and 2016/17 seasons and on 'Zaghloul', only 2016/17 season. Three random crates samples, $16 \mathrm{~kg}$ each, which represent about $5 \%$ of total harvested amount daily that, weighs around $1000 \mathrm{~kg}$ of above-mentioned cultivars at commercial harvesting 
date of each cultivar usually practiced in the farm for many years. Each sample was examined and separated into two sets, sound fruits (free of visible defects) and defected/ discarded set, the percentages of sound and discarded fruits were calculated.

The defected fruit set was examined and separated according to the type of defect; each defect in the discarded set was calculated as a percentage of the total weight of the defected fruit set. The following are the types of defects were used for the examination and separation: 1) Misshape, the fruit was considered misshaped when it shows abnormal/irregular characteristic of the cultivar. 2) Unpollinated dates (shees), dates not pollinated as evidenced by thin flesh, immature characteristics and no pit in unpetted dates (Codex Stan 143-1985). 3) Decay, dates that are in a state of decomposition and very objectionable in appearance, (Codex Stan 143-1985). 4) Dirt, dates contaminated with sand, soil, dust or other field debris and particles are not easy to be removed. 5) Discolored, when the color of dates does not present the possess characteristic color for the cultivar 6) dry dates, 7) Insect damage, dates damaged by insects or mites or contaminated by damage and contamination the presence of dead insects or mites, fragments of insects or mites or their excreta (Codex Stan 143-1985). 8) Over ripped, fruits transformed from Bisr into Rutab stage 9) Shrivelling, date loses the moisture content causing wrinkling in fruit surface. 10) Under size, when number of fruits in half $\mathrm{kg}$ are more than 23 fruits for 'Samani' and 'Zaghloul' cultivars and more than 100 fruits for 'Oreebi', 'Hayani' and 'Bent Aisha' cultivars (Codex Stan 143-1985). 11) Unripe dates, dates which may be light in weight, light in color, have shrivelled or little flesh or a decidedly rubbery texture (Codex Stan 143-1985). 12) Without calyx, 13) Mechanical injuries, any type of mechanical cracked or mashed or bruises on fruit surface. The data were managed as a randomized complete block design with three replicates $(n=3)$. Data were analyzed by Assistat software version 7.7, program last update was on 08/10/2014 according to Little and Hills (1972). Means were compared using Duncan's new multiple-range test at $P$ value $\leq 0.05$ (Duncan, 1965).

Financial value of defected date fruits (loss) at harvesting in Egyptian pounds (EGP): was calculated for each cultivar as follows:

$$
\text { Production (ton) } \times \% \text { of loss at harvesting } \times \text { Farm get price } / \text { ton (US\$) }
$$

Loss in cropping-land (area used to produce lost amount of dates) Fed, was calculated as follows:

$$
\text { Total production area (hectare) } \times \% \text { of loss at harvesting }
$$

Loss of production cost was calculated as follows:

$$
\text { Loss in cropping-land (hectare) } \times \text { production cost }(\mathrm{US} \$) / \mathrm{Fed}
$$

Loss of irrigation water $\left(\mathrm{m}^{3}\right)$ used to produce the lost amount of date fruits of each cultivar as follows:

$$
\text { Loss in cropping-land (hectare) } \times \text { Water requirements per Fed }\left(\mathrm{m}^{3}\right)
$$




\section{Results and discussion}

\section{Amount of sound and defected (loss) date palm fruits at harvesting time}

The results in Tables 1 and 2 showed that, the percentages of the sound, non-defected fruits at harvesting time and total discarded percentage/defected fruits of 'Samani', 'Oreebi', 'Hayani', 'Bent Aisha' and 'Zaghloul' cultivars during 2016 and 2017 seasons. The sound date palm fruits percentage was $84.32,83.21,76.97$, and $73.23 \%$ for 'Bent Aisha', 'Oreebi', 'Samani', and 'Hayani' in 2016 season, respectively. While during second season (2017), it recorded 94.50, 90.34, 80.34, 75.00\% and $74.67 \%$ for 'Zaghloul', 'Bent Aisha', 'Hayani', 'Oreebi' and 'Samani' respectively. Regarding the defected fruits, 'Hayani' cultivar showed that, the highest fruit loss at harvesting time was 26.77 percentage during 2016 season more than one quarter of its production, followed by 'Samani' cultivar (23.03\%), the differences were not significant. On the other hand, lossing fruits of 'Oreebi' and 'Bent Aisha' cultivars were 16.79 and $15.68 \%$ during harvesting time in the same season, respectively, with no significant differences between them. The losses of both cultivars at harvested time were significantly lower than 'Hayani' and 'Samani' cultivars.

In 2017 season, loss fruit of 'Samani' and 'Oreebi' cultivars were almost equal quantities; $25 \%$ of the produced fruits at harvested time and the differences between them was not significant followed by 'Hayani' 19.66 and 'Bent Aisha' 9.00\%, respectively. While the lowest fruit loss was recorded by 'Zaghloul' cultivar (5.50\%).

The obtained results showed that loss at harvested of soft dates is substantial. These results are in consistent with those of Kader and Rolle (2004) who found that the magnitude of fruit losses depends, among other factors, on the nature of the commodities and the conditions of the produce at the time of collections. This also accords with FAO study in 2011 and Yahia et al. (2014), they reported that, low technical capacities in harvesting performances is one of the reasons of fruit loss, also El-Habbab et al. (2017) concluded that, the level of loss at harvesting time differs from area to area and from cultivar to another. Similar findings were observed on orange (Salama et al., 2015). So, the management practices of harvesting process play significant role in reducing loss during this stage and next stages in dates supply chain. The relatively low loss of 'Zaghloul' could be attributed to the differences between growers in practicing harvesting techniques and processes.

\section{Type of soft date fruit defects (loss) at harvesting time}

Results in Tables 1 and 2 present the percentages of different types of defects in the discarded fruit set. Fruits without calyx (Fig. 1) are the main defect of all studied cultivars in both seasons except 'Oreebi' cultivar, it was discoloration in both seasons. In the first seasons 2016 (Table 1), 'Hayani' cultivar, showed the highest without calyx defect $(41.70 \%)$ followed by 'Bent Aisha' (39.93\%), the difference between them were not significant, while 'Samani' cultivar $(20.48 \%)$ was significantly lower than both. 'Oreebi' cultivar showed the lowest significant without calyx defect. In the second 2017 season (Table 2), 'Hayani' cultivar, also showed the highest without calyx defect (56.29\%) followed by 'Bent Aisha' (55.38\%) and 'Samani' (53.78\%) cultivars respectively, the differences between them were not significant. 'Zaghloul' cultivar (31.08\%) was significantly lower than 'Hayani', 'Bent Aisha' and 'Samani' while 'Oreebi' showed the lowest significant difference. This is could be attributed to the harsh way of fruit separation from the strands, which led mostly to the separation of part 
of the fruit flesh with the cap (calyx), as shown in Photo 1. Fruits without calyx (cap) are more subjected to microorganisms and insect's infestation.

Table 1. Sound, defected date fruits and types of defects as percentage of total sample weight of some soft date palm cultivars at harvesting time in North Delta, Egypt during 2016 season

\begin{tabular}{c|c|c|c|c}
\hline Cultivars & 'Samani' & 'Bent Aisha' & 'Hayani' & 'Oreebi' \\
\hline Sound fruits (\%) & $76.97 \mathrm{ab}$ & $84.32 \mathrm{a}$ & $73.23 \mathrm{~b}$ & $83.21 \mathrm{a}$ \\
Defected fruits (\%) & $23.03 \mathrm{a}$ & $15.68 \mathrm{~b}$ & $26.77 \mathrm{a}$ & $16.79 \mathrm{~b}$ \\
\hline \multicolumn{4}{|c}{ Causes of defects } \\
\hline Misshaped & $0.57 \mathrm{~b}$ & $0.00 \mathrm{~b}$ & $0.61 \mathrm{~b}$ & $3.72 \mathrm{a}$ \\
Unpollinated dates (Shees) & $0.00 \mathrm{a}$ & $0.00 \mathrm{a}$ & $0.00 \mathrm{a}$ & $0.67 \mathrm{a}$ \\
Decay and mold & $2.56 \mathrm{a}$ & $0.00 \mathrm{~b}$ & $0.32 \mathrm{~b}$ & $0.00 \mathrm{~b}$ \\
Dirt & 0.00 & 0.00 & 0.00 & 0.00 \\
Discolored & $9.36 \mathrm{~b}$ & $3.74 \mathrm{~b} \mathrm{c}$ & $1.72 \mathrm{c}$ & $69.83 \mathrm{a}$ \\
Dry dates & $0.46 \mathrm{~b}$ & $5.64 \mathrm{a}$ & $0.24 \mathrm{~b}$ & $0.62 \mathrm{~b}$ \\
Insect damage & $4.59 \mathrm{a}$ & $2.89 \mathrm{ab}$ & $0.00 \mathrm{~b}$ & $0.85 \mathrm{ab}$ \\
Over ripped & $0.58 \mathrm{~b}$ & $0.52 \mathrm{~b}$ & $0.00 \mathrm{~b}$ & $11.80 \mathrm{a}$ \\
Shriveling & $0.50 \mathrm{c}$ & $7.31 \mathrm{a}$ & $0.77 \mathrm{c}$ & $2.58 \mathrm{~b}$ \\
Unripe Dates & 0.00 & 0.00 & 0.00 & 0.00 \\
Without calyx & $20.48 \mathrm{~b}$ & $39.93 \mathrm{a}$ & $41.70 \mathrm{a}$ & $5.76 \mathrm{c}$ \\
Wounds & $3.63 \mathrm{a}$ & $0.00 \mathrm{~b}$ & $0.35 \mathrm{~b}$ & $0.00 \mathrm{~b}$ \\
\hline
\end{tabular}

Values with the same letter in the same raw are not significant at $(\mathrm{P} \geq 0.05)$

Table 2. Sound, defected date fruits and types of defects as percentage of total sample weight of some soft date palm cultivars at harvesting time in North Delta, Egypt during 2017 season

\begin{tabular}{c|c|c|c|c|c}
\hline Cultivars & 'Samani' & 'Bent Aisha' & 'Hayani' & 'Oreebi' & 'Zaghloul' \\
\hline Defect \% & $75.33 \mathrm{~d}$ & $90.33 \mathrm{~b}$ & $80.33 \mathrm{c}$ & $75.00 \mathrm{~d}$ & $94.50 \mathrm{a}$ \\
Defected fruits (\%) & $25.33 \mathrm{a}$ & $9.66 \mathrm{c}$ & $19.66 \mathrm{~b}$ & $25.00 \mathrm{a}$ & $5.50 \mathrm{~d}$ \\
\hline \multicolumn{5}{|c}{ Causes of defects } \\
\hline Misshaped & $8.70 \mathrm{~b}$ & $0.00 \mathrm{c}$ & $2.83 \mathrm{c}$ & $0.00 \mathrm{c}$ & $21.17 \mathrm{a}$ \\
Unpollinated dates (Shees) & $1.19 \mathrm{~b}$ & $0.00 \mathrm{~d}$ & $0.42 \mathrm{c}$ & $5.02 \mathrm{a}$ & $1.45 \mathrm{~b}$ \\
Decay and mold & $3.87 \mathrm{a}$ & $0.00 \mathrm{c}$ & $0.39 \mathrm{bc}$ & $0.60 \mathrm{~b}$ & $0.00 \mathrm{c}$ \\
Drit & $3.52 \mathrm{a}$ & $0.43 \mathrm{~b}$ & $0.00 \mathrm{~b}$ & $0.00 \mathrm{~b}$ & $0.00 \mathrm{~b}$ \\
Discolored & $6.97 \mathrm{bc}$ & $2.02 \mathrm{c}$ & $5.32 \mathrm{bc}$ & $55.52 \mathrm{a}$ & $9.93 \mathrm{~b}$ \\
Dry dates & $0.11 \mathrm{a}$ & $0.17 \mathrm{a}$ & $0.42 \mathrm{a}$ & $0.25 \mathrm{a}$ & $0.00 \mathrm{a}$ \\
Insect damage & $4.23 \mathrm{ab}$ & $1.80 \mathrm{bc}$ & $1.44 \mathrm{bc}$ & $0.40 \mathrm{c}$ & $0.00 \mathrm{c}$ \\
Over ripped & $0.00 \mathrm{~b}$ & $0.55 \mathrm{~b}$ & $4.70 \mathrm{a}$ & $0.60 \mathrm{~b}$ & $0.00 \mathrm{~b}$ \\
Shriveling & $1.68 \mathrm{~b}$ & $1.82 \mathrm{~b}$ & $9.13 \mathrm{a}$ & $0.30 \mathrm{~b}$ & $0.00 \mathrm{~b}$ \\
Unripe dates & $0.17 \mathrm{a}$ & $0.00 \mathrm{a}$ & $0.00 \mathrm{a}$ & $0.00 \mathrm{a}$ & $0.00 \mathrm{a}$ \\
Without calyx & $53.78 \mathrm{a}$ & $55.38 \mathrm{a}$ & $56.29 \mathrm{a}$ & $13.34 \mathrm{c}$ & $31.08 \mathrm{~b}$ \\
Wounds & $0.37 \mathrm{~b}$ & $0.00 \mathrm{~b}$ & $0.14 \mathrm{~b}$ & $0.00 \mathrm{~b}$ & $2.27 \mathrm{a}$ \\
\hline
\end{tabular}

Values with the same letter in the same raw are not significant at $(\mathrm{P} \geq 0.05)$ 


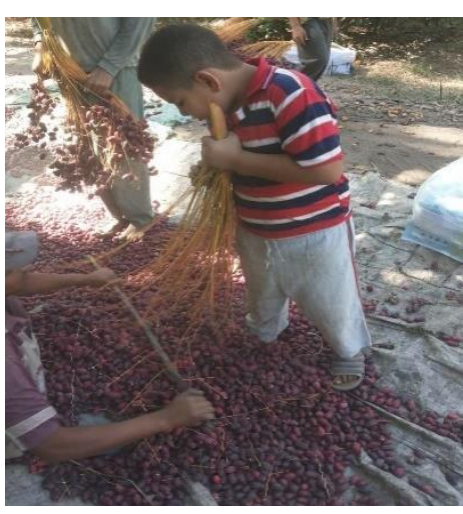

A

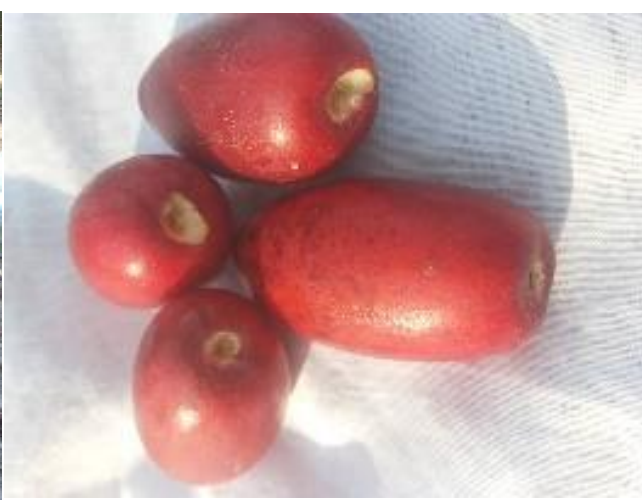

B

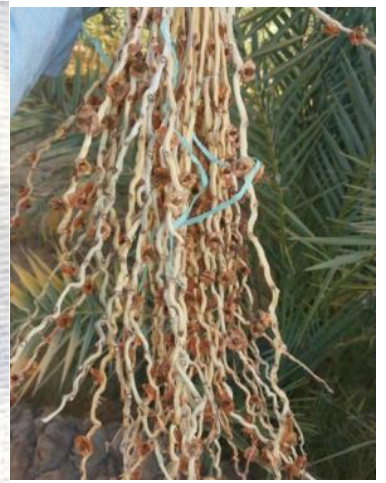

C

Figure 1. Severe losses occurred due to careless rough handing of dates by farmers. A) rough way of separating the fruits from the branches (strands) using stick, B) separation of part of the fruit flesh with the cap (calyx), C) strands full of caps

Discoloration defect was significantly the highest in 'Oreebi' cultivar during both seasons, $69.83 \%$ and $55.52 \%$ respectively. In the first season, the difference between 'Bent Aisha', 'Hayani' was not significant while 'Samani' was significantly higher than both. In the second season, there was no significant difference neither between 'Hayani', 'Zaghloul' and 'Samani' cultivars nor 'Hayani' 'Bent Aisha' and 'Samani' while the difference between 'Zaghloul' and 'Bent Aisha' was significant.

During the both seasons, unpollinated dates (shees), decay, dirt, insect damage, unripe fruit and mechanical injuries defects for all cultivars were low and ranged from around 0.00 to almost $5.00 \%$. The same was also observed for dry dates defect except for 'Bent Aisha' cultivar in the first season, 5.64\% significantly higher than the rest of the studied cultivars. Over ripening defect showed the same lower trend except for 'Oreebi' cultivar in the first season (11.80\%), it was significantly higher than the other studied cultivars. Shriveling defect showed also the same lower trend except for 'Bent Aisha' cultivar during the first season (7.31\%) and 'Hayani' (9.13\%) in the second season, significantly higher than the rest of the studied cultivars.

Results showed that the main causes of fruit loss at harvest under North Delta conditions were fruit without calyx (cap) for 'Samani', 'Bent Aisha', 'Hayani', and 'Zaghloul' cultivars and discoloration defect for 'Oreebi' cultivar. Fruit of the studied cultivars were less susceptible to insect damage, decay, dry dates, misshape, and unpollinated fruit (shees). These results are in consistent with those of Kereth et al. (2013) who stated that mechanical damages were the main type of fruit defect at harvest (79\%) in Tanzania. El-saedy (2011) found that the fallen cap (calyx) of 'Hallawy' and 'Zaghloul' fruit triggered a high increase in polyphenol oxidase and peroxidase activity that resulted in negative effect on fruit weight loss, peel anthocyanin content, soluble solids, malic acid and total phenol content, which in turn led to quick fruit deterioration during cold storage at $1{ }^{\circ} \mathrm{C}$. This is pointed out to the need of improving harvest methods, Yahia et al. (2014) and Kader and Awad (2009) reported that in Arabian Peninsula countries, mechanical damage are the common types of postharvest loss of dates. El-Habbab et al. (2017) stated that dates loss at harvest time of three cultivars in four locations in Saudi Arabia, include shees \& besr, birds damage, falling, insects and dust mite which is not the case for the studied soft dates cultivars under North Delta conditions. Elsayed and Abdel Gleel (2013), in Egypt, have reported that, the average 
dates loss of ten-year (2000-2010) at harvesting were $10-15 \%$ and $8.1 \%$ during postharvest processes, this is due to mechanical (harvesting, sorting, grading, and transportation) or biological (pests and insects) reasons.

\section{Financial value of the defected (loss) date fruits at harvesting}

The Total value of dates loss of the studied cultivars during 2016 and 2017 were $9,232,793$ and 8,641,908.89 (US\$) based on farm gate price of 2014, (Table 3). The results showed that, the highest value loss in both seasons were corresponding to 'Hayani' cultivar, 6,546,601.99 and 4,634,720.74 (US\$) respectively, followed by 'Samani' cultivar 1,986,639.19 and 2,185,044.32 (US\$) for both seasons respectively. 'Zaghloul' ranked the third with 1,215,153.39 US\$ in 2017 followed by 'Bent Aisha' 497,908.44 and 306,747.16 US\$ for 2016 and 2017 respectively.

Table 3. Financial value (EGP) of date fruits loss at harvesting of some soft date palm cultivars in North Delta, Egypt during 2016 and 2017 seasons

\begin{tabular}{|c|c|c|c|c|c|c|}
\hline \multirow[t]{2}{*}{ Cultivar } & \multirow{2}{*}{ 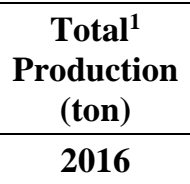 } & \multicolumn{2}{|c|}{$\% \operatorname{loss}^{2}$} & \multirow{2}{*}{$\begin{array}{c}\text { Farm gate } \\
\text { price/ton in } \\
2016(\mathrm{US} \$)^{3}\end{array}$} & \multicolumn{2}{|c|}{$\begin{array}{c}\text { Loss (US\$), based on farm gate } \\
\text { price/ton }\end{array}$} \\
\hline & & 2016 & 2017 & & 2016 & 2017 \\
\hline 'Zaghloul' & 170,025 & - & 5.50 & 129.94 & - & $1,215,153.39$ \\
\hline 'Hayani’ & 335,699 & 27.77 & 19.66 & 70.22 & $6,546,601.99$ & $4,634,720.74$ \\
\hline 'Bent Aisha' & 45,327 & 15.68 & 9.66 & 70.06 & $497,908.44$ & $306,747.16$ \\
\hline 'Samani' & 101,486 & 23.03 & 25.33 & 85.00 & $1,986,639.19$ & $2,185,044.32$ \\
\hline 'Oreebi' & 17,143 & 16.79 & 25.00 & 70.06 & $201,643.38$ & $300,243.27$ \\
\hline \multicolumn{5}{|c|}{ Total } & $9,232,793.00$ & $8,641,908.89$ \\
\hline
\end{tabular}

${ }^{1}$ Source: Ministry of Agriculture and Land Reclamation, Economic Affairs Sector (2018). The last available statistical issue for production is 2016, so we used it for both 2016 \& 2017 seasons

${ }^{2}$ Results of this work in Table 1

${ }^{3}$ Source: Ministry of Agriculture and Land Reclamation, Economic Affairs Sector (2016). The last available statistical issue for Farm gate price is 2016, so we used it for both 2016 \& 2017 seasons

${ }^{4}$ Calculated by Equation 1 from columns 1, 2 and 3 (1 US\$ = 17.8 Egyptian pound (EGP))

\section{Loss of irrigation water and cropping-land and production cost (EGP) as a result of fruit defects (Loss) of some soft date palm cultivars at Harvesting}

The irrigation water that has been used to produce the lost percentage of date fruits at harvesting, is considered an important lost as well taking into consideration that Egypt suffers from water shortage (Omar and Moussa, 2014). It was 5,242,919, 3,987,674, 1,325,155 and 666,340 $\mathrm{m}^{3}$ for 'Hayani', 'Samani', 'Oreebi' and 'Bent Aisha' in 2016 respectively. In 2017, it was 4,385,922, 3,711,768, 1,973,132, 1,804,411 and 410,513 'Samani', 'Oreebi', 'Hayani', 'Zaghloul' and 'Bent Aisha' respectively (Table 4). These differences due to the differences in the cultivated areas. The average water loss was $11,222,087$ and 12,285,744 $\mathrm{m}^{3}$ for 2016 and 2017 respectively. This amount of water was used to irrigate around $14 \%$ and $15 \%$ of date palm cropland during 2016 and 2017 seasons.

Water requirements for date palm vary from region to another according to climate conditions as well as the irrigation method, where it is $15,000-35,000 \mathrm{~m}^{3} / \mathrm{ha}$ in Algeria, 
23,600 in Tunisia, 13,000-20,000 in Morocco, 15,000-20,000 in Iraq, where it is 22,300 $\mathrm{m}^{3} /$ ha in Egypt (Albaker, 1972; Liebenbag and Zaid, 2002; Kassem, 2007).

Table 4. Estimated loss of irrigation water (million $\mathrm{m}^{3}$ ), cropping land (ha) and production cost (US\$) because of defected fruits (loss) at harvesting of some soft date palm cultivars in North Delta, Egypt during 2016 and 2017 seasons

\begin{tabular}{|c|c|c|c|c|c|c|c|c|c|}
\hline \multirow[t]{2}{*}{ Cultivar } & \multirow[t]{2}{*}{$\begin{array}{c}\text { Total }^{1} \\
\text { cultivated } \\
\text { area (ha) }\end{array}$} & \multicolumn{2}{|c|}{$\operatorname{Loss}(\%)^{2}$} & \multicolumn{2}{|c|}{$\begin{array}{l}\text { Loss in cropping- } \\
\quad \text { land }(\mathrm{ha})^{3}\end{array}$} & \multicolumn{2}{|c|}{$\begin{array}{l}\text { Production cost } \\
\text { Loss }(\mathrm{US} \$)^{4}\end{array}$} & \multicolumn{2}{|c|}{$\begin{array}{c}\text { Loss of irrigation } \\
\text { water }\left(\text { million } \mathbf{m}^{3} \text { ) }\right. \\
\text { (water requirement } \\
\text { equal to } \\
\left.6333.18 \mathbf{~ m}^{3} / \mathbf{h a}\right)^{5}\end{array}$} \\
\hline & & 2016 & 2017 & 2016 & 2017 & 2016 & 2017 & 2016 & 2017 \\
\hline 'Zaghloul' & $5,180.25$ & 0 & 5.5 & 0.00 & 284.91 & - & 243,054 & - & $1,804,410$ \\
\hline 'Hayani’' & 2,981.09 & 27.77 & 19.66 & 127.85 & 586.08 & 706,221 & 499,957 & $5,242,915$ & $3,711,765$ \\
\hline 'Bent Aisha' & 671.01 & 15.68 & 9.66 & 105.85 & 64.82 & 89,756 & 55,296 & 666,342 & 410,514 \\
\hline 'Samani' & $2,734.03$ & 23.03 & 25.33 & 629.65 & 692.53 & 537,139 & 590,783 & $3,987,668$ & $4,385,916$ \\
\hline 'Oreebi' & $1,246.22$ & 16.79 & 25 & 209.24 & 311.56 & 178,499 & 265,782 & $1,325,157$ & $1,973,134$ \\
\hline Total & $12,812.60$ & & & $1,771.9$ & $1,939.9$ & $1,511,616$ & $1,654,890$ & $11,222,082$ & $12,285,738$ \\
\hline
\end{tabular}

${ }^{1}$ Source: Ministry of Agriculture and Land Reclamation, Economic Affairs Sector (EAS), Bulletin of the Agricultural Statistics, Part (2) 2018

${ }^{2}$ Results of this work in Table 1

${ }^{3}$ Calculated by Equation 2, from columns $1 \& 2$

${ }^{4}$ Calculated by Equation 3, based on production cost/Fed equal to 15,185 EGP, source: Ministry of Agriculture and Land Reclamation, Economic Affairs Sector (EAS), 2017

${ }^{5}$ Calculated by Equation 4. Water requirements for Date palm in North Delta Region $=2661 \mathrm{~m}^{3} / \mathrm{Feddan}$ and $6333.18 \mathrm{~m}^{3} / \mathrm{ha}$ as One Feddan (Fed), equal to 0.39 ha. Source: Hassanien et al. (2012)

\section{Conclusion}

1. The percentages of fruit loss was 19.66- 26.77, 23.03-25.33, 16.79-25.00, 9.66-15.68, and 5.55\% for 'Hayani', 'Samani', 'Oreebi', 'Bent Aisha' and 'Zaghloul' cultivars respectively.

2. The total financial value of date fruit loss was based on farm price (US\$), which was 9,232,793 and 8,641,908 US\$.

3. The total loss in terms of cropping land was $1764.44-1931.38$ ha with a total loss in production cost $=3.59-3.93$ million US\$ and a loss in irrigation water $=11,2-12,3$ million $\mathrm{m}^{3}$.

4. The main fruit defect of 'Hayani', 'Samani', 'Bent Aisha' and 'Zaghloul' at harvesting in north delta area is Fruits without calyx (cap), while for 'Oreebi' cultivars is discoloration.

5. At harvesting, defects because of insect damage, decay, dry dates, misshape, and unpollinated fruit (shees) were low and ranged from around 0 to $5 \%$.

6. There is a need for training programs on good agricultural practices of dates.

Acknowledgements. The authors would like to thank Dr. Samahy, Vegetable Crop Research Station, Horticulture Research Institute, for his help in statistical analysis. 


\section{REFERENCES}

[1] Albaker, A. (1972): Date Palm Trees. - Ministry of Higher Education, Baghdad, Iraq (in Arabic).

[2] Boye, J., Muck, O. (2015): Conclusions from 30 Years of Practical Postharvest Loss Prevention Work. - Abstract \#ADMI024 P. 55-57 The First International Congress on Postharvest Loss Prevention. Development Measurement Approaches and Intervention Strategies for Smallholders. Rome, Italy, October 4-7, 2015.

[3] Chao, C. T., Krueger, R. R. (2007): The date palm (Phoenix dactylifera L.): overview of biology, uses, and cultivation of biology, uses, and cultivation. - Hortscience 42(5): 1077-1082.

[4] Codex Standard for Dates (Codex Stan 143-1985): https://www.google.com/search?q=Codex+for+dates\&oq=Codex+for+dates\&aqs=chrom e.69i57j012.20051j0j4\&sourceid=chrome\&ie=UTF-8. - Accessed at 03. 01. 2019.

[5] Duncan, D. B. (1965): Multiple ranges and multiple F test. - Biomet. 11: 1-42.

[6] El-Habbab, M. S., Al-Mulhim, F., Al-Eid, S., Abo El-Saad, M., Aljassas, F., Sallam, A., Ghazzawy, H. (2017): Assessment of post-harvest loss and waste for date palms in the Kingdom of Saudi Arabia. - International Journal of Environmental \& Agriculture Research (IJOEAR) 3(6): 1-11.

[7] El-saedy, R. M. A. (2011): Pomological characteristics and postharvest behavior of Hallawy and 'Zaghloul' date fruits during cold storage. - Zagazig, J. Agric. Res. 38(3): 587-606.

[8] El-Sayed, E. A., Abdel Gleel, S. S. (2013): An economic analysis for production and exports of date in Egypt. - J. Agric. Econom. Social Sci., Mansoura Univ. 4(9): 17711783.

[9] FAO (2011): Global Food Losses and Food Waste. Extent, Causes and Prevention. FAO, Rome.

[10] FAO (2016): Strategy for the Development of Date Palm and Dates Sector in Egypt. http://www.fao.org/egypt/resources/ar/ (accessed on 29.01.2019).

[11] FAO (2019): Data for Crop Production in 2017. - http://www.fao.org/faostat/en/\#data (accessed on 25/1/2019).

[12] Hassanien, M. K., Ahmed, M. A., Hashem, F. A., Khalil, A. A., Refaie, K. M. (2012): Management of Deficit Water for Crops in Egypt. - Central Laboratory for Agricultural Climate, Agriculture Research Center, Giza, Egypt.

[13] Kader, A. A., Awad, H. (2009): Harvesting and Postharvest Handling of Dates. ICARDA, Aleppo, Syria.

[14] Kader, A., Rolle, R. S. (2004): The Role of Post-Harvest Management in Assuring the Quality and Safety of Horticultural Produce. - FAO, Rome, Italy.

[15] Kassem, M. A. (2007): Water requirements and crop coefficient of date palm trees "Sukariah CV.". - Misr Journal Agricultural Engineering 24(2): 339-359.

[16] Kereth, G. A., Monica Lyimo, M., Hadijah, A. Mbwana, H. A., Mongi, R. J., Carolyne, C. Ruhembe, C. C. (2013): Assessment of post-harvest handling practices: knowledge and losses of fruits in Bagamoyo District of Tanzania. - Food Science and Quality Management 11: 8-15.

[17] Lemlem, A., Alemayehu, M., Endris, M. (2018): Date palm production practices and constraints in the value chain in Afar Regional State, Ethiopia. - Hindawi Advances in Agriculture 6469104. https://doi.org/10.1155/2018/6469104.

[18] Liebenbag, P. J., Zaid, A. (2002): Date Palm Irrigation. - FAO Plant Production and Protection Papers, 156 Rev. 1.

[19] Little, T. M., F. J. Hills. (1972): Statistical Methods in Agricultural Research. - Univ. California, Davis, CA, USA. 
[20] Ministry of Agriculture and Land Reclamation, Economic Affairs Sector (EAS) (2016): Bulletin of the Agricultural Statistics, Part (2), Summer \& Nili Crops, 2015. - Ministry of Agriculture and Land Reclamation, Dokka.

[21] Ministry of Agriculture and Land Reclamation, Economic Affairs Sector (EAS) (2017): Bulletin of The Agricultural Statistics, Part (2), Summer \& Nili Crops, vegetables \& Fruits, 2016. - Ministry of Agriculture and Land Reclamation, Dokka.

[22] Ministry of Agriculture and Land Reclamation, Economic Affairs Sector (EAS) (2018): Bulletin of The Agricultural Statistics, Part (2), Summer \& Nili Crops, vegetables \& Fruits, 2016. - Ministry of Agriculture and Land Reclamation, Dokka

[23] Omar, M. E. M., Moussa, A. M. A. (2014): Water management in Egypt for facing the future challenges. - Journal of Advanced Research 7(3): 403-412.

[24] Salama, A., Ansary, M., Elmorsy, A., El-Hamady, M. (2015): Survey of defects of orange in Egypt that affect its acceptability for exportation. - 1st International Congress in Postharvest Loss Prevention held in Rome, Italy (4-7 October).

[25] Yahia, E. M., Lobo, M. G., Kader, A. A. (2014): Harvesting and Postharvest Technology of Dates. - In: Siddiq, M., Aleid, S. M. (eds.) - Dates: Postharvest Science, Processing Technology and Health Benefits. Wiley Blackwell, Hoboken, NJ, pp.108-113. 